\title{
IDENTIFIACTION AND AUTHENTICATION OF Persons in Cyberspace in Selected States
}

\author{
Jozef Andraško \\ Comenius University in Bratislava, Faculty of Law, Slovak Republic \\ jozef.andrasko@flaw.uniba.sk
}

ANDRAŠKO, Jozef. Identifiaction and Authentication of Persons in Cyberspace in Selected States. International and Comparative Law Review, 2018, vol. 18, no. 1, pp. 199-216. DOI: 10.2478/iclr-2018-0032.

\begin{abstract}
Summary: The author analyses different models of identification and authentication in selected states. First of all, the author explains the reason for choosing countries in question. Secondly, the author briefly analyses fundamental strategic documents and legal acts relating to eGovernment, in particular identification and authentication. In addition, the specific electronic identification means used in selected states will be analyzed. The analyze of different models of identification and authentication in selected states can lead to the identification of differences that arose within the comparison of various models. In the end, the author will summarize positive and negative aspects of analyzed models of identification and authentication. These findings are necessary in order to make a conclusion which electronic identification means could be applied in the Slovak Republic.
\end{abstract}

Keywords: identification, authentication, electronic identification means, eGovernment services

\section{Introduction}

The arrival of modern information and communication technologies (hereinafter referred to as "ICTs") and their introduction into public administration activities caused the development of new identification and authentication ${ }^{1}$ models for purposes of provision and use of eGovernment services ${ }^{2}$. In this con-

1 In general, the identification means declaring of identity. Authentication means proofing of declared identity. Authentication of persons can be based on what person knows (password, PIN etc.), what person has (ID card, certificate) or what person is (biometric characteristics like fingerprints, voice etc.). More on identification and authentication in: ANDRAŠKO Jozef. Electronic identification and authentication in the context of electronic public administration services. In CER Comparative European research 2016, iss. 2, London: Sciemcee publishing, 2016, p. 75-78. [online]. Available at: $<$ http://www. cer-sciemcee.com/previous-years $>$.

2 In literature, it is possible to find also terms like public administration electronic services, electronic public service, public online service, digital electronic service, and so on. These terms can be considered as synonymous with the term eGovernment services. More on

Published by Palacký University Olomouc, Czech Republic, 2018.

ISSN (print): 1213-8770; ISSN (online): 2464-6601 
text, states have built new models of identification and authentication, either on the basis of existing identification and authentication methods that have been applied in the physical world or by creating new models that can only be applied in the cyberspace ${ }^{3}$. Countries like Kingdom of Denmark (hereinafter referred to as "Denmark"), Republic of Estonia (hereinafter referred to as "Estonia") and New Zealand apply different approaches to the issue of identification and authentication of persons in cyberspace as in the cases of the Slovak Republic (hereinafter referred to as "Slovakia"). These differences can be beneficial for proposals de lege ferenda in the Slovak legal order.

\section{Slovakia}

Slovakia is a country with a long tradition of using physical identity card in order to prove the identity of citizens. Introduction of modern ICTs into public administration challenged Slovak legal order in many ways. It was necessary to ensure in order public authorities knew with whom they communicate at a distance, who submits applications, to whom they have to deliver the official documents and how they can be signed with the legal effects of a handwritten signature.

\section{1 eGovernment in Slovakia}

The issue of identification and authentication is connected with society informatization and introduction of ICTs into public administration. Numerous strategic documents have been adopted in these fields, but only a few of them are directly concerned with identification and authentication and institutes related to it. The key strategy is the National Concept of Informatisation of Public Administration (2008). The concept in question defines, inter alia, the architecture of the integrated information system of public administration in order public administration could provide information, communication, and transactional electronic services to the public through various access channels while creating the preconditions for their efficient provision.

The primary legal act regulating identification and authentication is Act No. 305/2013 Coll. on the Exercise of Public Authorities Competences in Electronic Form and on changes and amendments to certain acts (hereinafter referred to as the "e-Government Act"). The creation of such a legal framework should contribute to the implementation of public authority electronic services in a uni-

the concept of eGovernment services in: ANDRAŠKO, Jozef. Theoretical aspects of public administration electronic services. In Bratislava law review, 2017, Vol. 1, Issue 2, p. 119 128.

3 See also: KERIKMÄE, Tanel; HOFFMANN, Thomas; CHOCHIA, Archil. Legal Technology for Law Firms: Determining Roadmaps for Innovation. Croatian International Relations Review, 2018,vol. 24, no, 81, p. 91-112. 
form manner, without interfering with any specific legislation that regulates the exercise in specific cases. ${ }^{4}$

\subsection{Identification and authentication}

Central public administration portal (hereinafter referred to as the "Central portal") which is information system of public administration, can be considered the main access point to eGovernment services. It is possible to centrally carry out official electronic communication with all public authorities through the Central portal. The administrator of the Central portal is the Government office of the Slovak Republic and its operator is the National Agency for Network and Electronic Services. Public authorities are obliged to publish correct and complete information regarding their own actions and electronic services provided. In other words, the Central portal ensures the access to electronic services provided by public authorities. ${ }^{5}$

Pursuant to Section 21 of the eGovernment Act, authenticators have to be used for authentication. In accordance with eGovernment Act, such an authenticator is identity card with electronic chip and personal security code (hereinafter referred to as "eID") or alternative authenticator. ${ }^{6}$

\section{$e I D^{7}$}

On the one hand, eID presents physical means for citizens of Slovakia, as well as foreigners with permitted residence in Slovakia. In other words, eID ensures a classical proof of identity. On the other hand, eID is considered means of identity proofing in an electronic environment. Such a function is necessary for access and use of eGovernment services. Issuing of eID in the Slovakia started in 2013.

4 The e-Government Act applies to public authorities. The term public authority (as an institution) is broader than the term public administration authorities. More on terminology and structure of public administration authorities in: ANDRAŠKO, Jozef, ŠURKALA, Ján. The concept of local self-government in the Slovak Republic. In Administrative law and process, 2015, Vol. 12, Issue 2, p. 321-332. [online]. Available at: <http://applaw.knu. ua/2015-2.pdf $>$.

5 Section 5 (1-5) of the e-Government Act.

6 The alternative authenticator is intended for natural persons who do not have an authorized residence in the territory of Slovakia. In other words, they do not meet the conditions of issuing an eID with a chip or a certificate of alien residence with a chip. Alternative authenticator serves exclusively to access and dispose of the electronic mailbox of the legal entity to which it was established. The purpose of introducing an alternative authenticator is to create conditions for a foreign statutory representative to entry and dispose of the electronic mailbox. See Section 21 (b) of the eGovernment Act and Decree of the Ministry of the Interior of the Slovak Republic no. 29/2017 Coll. which sets out the details of the alternative authenticator.

7 The eID was created by the implementation of an electronic chip into EU-format card issued in Slovakia from July 2008. The eID is issued from December 2013 and the Ministry of the Interior of the Slovak Republic has issued more than 2 million eID cards in Slovakia. 
It is necessary to point out that eID became secure means of identification and authentication in cyberspace via personal data that are stored in the electronic chip. ${ }^{8}$ It is also possible to store qualified certificate for qualified electronic signature and a key pair (public key and private key).

Inevitable precondition for using eID for access and using eGovernment services is its activation. Determination of security personal code (hereinafter referred to as "SPC") is a part of the activation process. SPC is a combination of six numbers chosen by the holder when submitting the application for eID issuance or later in person at the District Headquarters of Police Force on specific request. Security of sensitive data that are stored in the chip is provided by security mechanisms, as well as SPC. Furthermore, eID is means of creating an electronic signature, in particular, qualified electronic signature.

The electronic chip which is located on the back of the eID contains data that is recorded or can be recorded into identity card pursuant to Section 3 (1-3) of the Act No. 224/2006 Coll. on Identity Cards and Amendment and Supplementation of Certain Act (hereinafter referred to as "Identity Cards Act)" (e.g. name, surname, date of birth, birth number, address, etc.). In addition, the electronic chip of the eID can contain up to three types of certificates:

a) qualified certificate (ACA) - serves for signature by qualified electronic signature, ${ }^{9}$

b) certificate for signing (PCA) - serves to authorize selected processes in the form of electronic signature for communication within the provided eGovernment services, ${ }^{10}$

c) encryption certificate (SCA) - serves to encrypt data for its holder within the provided eGovernment services.

The electronic chip may also contain a private key and a public key (cryptographic keys) that are necessary for the creation or, respectively, verification of a qualified electronic signature.

8 Personal data are processed in the process of identification and authentication. It is necessary to respect rules stated in Regulation (EU) 2016/679 of the European Parliament and of the Council of 27 April 2016 on the protection of natural persons with regard to the processing of personal data and on the free movement of such data, and repealing Directive 95/46/EC (General Data Protection Regulation), among others, privacy by design. More on the issue of privacy by design in: MESARČÍK, Matúšs. Naozaj sa bojím tmy? Zopár úvah o technologickom determinizme v kontexte ochrany osobných údajov. In Acta Facultatis Iuridicae Universitatis Comenianae, 2017. Vol. 36, No. 2, p. 204-217.

9 Qualified certificate pursuant to Article 3 (15) of the Regulation (EU) No 910/2014 of the European Parliament and of the Council of 23 July 2014 on electronic identification and trust services for electronic transactions in the internal market and repealing Directive 1999/93/EC (hereinafter referred to as the "eIDAS Regulation").

10 Certificate for electronic signature pursuant to Article 3 (14) of the eIDAS Regulation. 
Public authorities are authorized to introduce and use different authentication methods for the specialized portals they manage. In practice, there will be cases when the person will be authenticated by password or GRID card. In the case where another authentication method is introduced, it is necessary to ensure the authentication of the person through eID and alternative authenticator.

\subsection{Entities responsible for identification and authentication}

District Headquarters of Police Force is responsible for eID issuance. Pursuant to Identity Card Act, a person can apply for an eID personally as well as through the portal of the Ministry of the Interior of the Slovak Republic. The request through the portal only applies to the issuance of a new identity card in statutory cases. ${ }^{11}$ Personalization of an eID (data recording on eID) is done centrally by the National Personalization Center of the Ministry of the Interior of the Slovak Republic. National Security Authority is the central government body for trust services pursuant to eIDAS Regulation.

\section{Denmark}

The reasons why I decided to analyze the issue of identification and authentication in Denmark are several. First of all, Denmark is a country with a rich tradition of eGovernment and is ranked at the forefront of various eGovernment evaluations. Secondly, Denmark does not have a physical identity card like a national identity card in the case of Slovakia. Citizens of Denmark prove their identity most often through registers in combination with paper documents such as a passport or a driving license. It will be interesting to see how this will be reflected in the way of identification and authentication in the cyberspace.

\section{1 eGovernment in Denmark}

Several strategic documents and legal acts were adopted in Denmark regarding eGovernment. The beginnings of eGovernment in Denmark are connected with the adoption of a strategy Towards eGovernment: Vision and Strategy for the Public Sector in Denmark (2001-2004). This document presented an eGovernment vision that should actively support the development of the information society and the public sector should operate and communicate electronically. An additional six strategies have been adopted since the adoption of the first eGovernment strategy. ${ }^{12}$ The last one was the Public Sector digitisation strategy 'A Stronger and more Secure Digital Denmark' (2016-2020) which, besides general issues such as the provision of public services of value to citizens and entrepre-

11 Pursuant to Identity Cards Act, there are two types of identity cards, in particular, the first identity card and new identity card.

12 The list of all strategies available at: <https://joinup.ec.europa.eu/sites/default/files/inlinefiles/eGovernment_in_Denmark\%20_March_2017_v2_00.pdf>. 
neurs, also deals with specific issues such as automation of processes in public administration, digital social security, data sharing etc.

As regards the eGovernment legislation in Denmark, it is necessary to point out that there is no comprehensive legislation in the Danish legal order which would regulate this field of law. The first legislation was adopted in 2012. The legislation in question regulated the mandatory use of specific public services in electronic form (so-called mandatory digital self-service). ${ }^{13}$

The adoption of the Public Digital Postal Act in 2012 has also been fundamental in the development of eGovernment. According to this act, public sector bodies have the right to send digital mail (e.g. messages, letters, documents, etc. $)^{14}$ to citizens of Denmark (older than 15) as a replacement for classical mail. Citizens have an obligation to receive digital mail from public sector bodies. ${ }^{15}$

\subsection{Identification and authentication}

Through the borger.dk website (Citizens' Portal), citizens have access to public information and public services provided by the public sector. Through the borger.dk, citizens can obtain personalized data (e.g., data about the last threemonth salary, tax information, etc.) and services regarding taxes, housing, data from citizens' register, etc. ${ }^{16}$

To access electronic services where identification and authentication is required, an electronic identification means called NemID has been used since 2010. This electronic identification means provides simple and secure access to a wide range not only of public services (public sector websites) but also of private sector services (e.g. electronic banking, access to private websites). To clarify this electronic identification means, I will describe how Danish citizens can obtain NemID and how it can be used.

In the first step, a citizen (citizen of Denmark older than 15 years, must have a civil registration number ${ }^{17}$ and a valid ID card, such as a driver's license, a health insurance card, etc.) may request to issue NemID online or physically in

13 It is possible to talk about four stages of the adoption of legislation, which established the obligation to use specific public services electronically. In the first stage, the change of address, the application for admission to primary school, the application for admission to the secondary school, the payment for the hunting license, etc. A complete list of all stages and specific public services available at: $<$ https://www.digst.dk/Servicemenu/English/Policy-and-Strategy/Mandatory-digital-self-service $>$.

14 E.g. hospital letters, retirement bills, sheets from central customs and tax administration, etc.

15 Specific exemptions from this obligation are laid down, for example, when it comes to homeless people, people who do not have access to a computer with sufficient internet connection in their home, etc. [online]. Available at: $<$ https://www.digst.dk/Servicemenu/ English/Policy-and-Strategy/Digital-Post-from-public-authorities $>$.

16 The Virk.de website is created for entrepreneurs.

17 The citizen registration number is the person identifier. 
the Citizens' Center. ${ }^{18}$ The citizen must indicate the citizen's registration number as well as the passport or driving license number in the application. In the second step, two letters will be delivered to the citizen by post. The first letter will contain the NemID card with codes. This card is the size of credit card and contains printed numbers (one-time passwords). The second letter will contain the NemID number that serves as the login name and also the password that will be used only at the first login. ${ }^{19}$

The citizen accesses eGovernment services through the NemLog-in authentication platform, where he enters the NemID number, password, and one-time password from the code card. It can be said that NemID is based on two-factor authentication, which consists of a login name, a password, and a one-time password. NemLog-in is a single sign-on solution, what means that a citizen can sign up for multiple service providers without having to identify and authenticate each time.

NemID can be used for digital signature creation. In this case, it is necessary to obtain a public certificate for electronic services (hereinafter referred to as "OCES") ${ }^{20}$. There are four types of OCES certificates, specifically:

a) OCES personal certificate (confirms the identity of the person),

b) OCES employee certificate (confirms the identity of a person and his or her status as an employee in an organization);

c) OCES business certificate (confirms that the certificate holder represents the particular company stated in the certificate);

d) OCES functional certificate (verifies requests, units, processes or services and ensures integrity and encryption in the communication between them. The main aim of the certificate in question is to ensure automated processes within the organization where authentication and integrity are required). ${ }^{21}$

\subsection{Entities responsible for identification and authentication}

The Danish Ministry of Finance is responsible for setting up initiatives to increase the efficiency of public administration in the field of identification and authentication. An important position has the State Digitization Office, which is part of the Danish Ministry of Finance. This office is responsible for the imple-

18 According to available sources, more than 70\% of Danes (over 15) have NemID. For more information see: THE EUROPEAN COMMISSION. eGovernment in Denmark. Brussels, 2016, p. 31.

19 The person can change the password as well as the login name after first signing in.

20 From the Danish designation Offentlige Certifikater til Elektronisk Service. For more information see <https://www.nemid.nu/dk-da/om-nemid/historien_om_nemid/ocesstandarden/oces-certifikatpolitikker/OCES_employee_certificates_version_4.pdf>.

21 [online]. Available at: <https://www.nemid.nu/dk-da/om-nemid/historien_om_nemid/ oces-standarden/oces-certifikatpolitikker/>. 
mentation of the objectives set out in adopted eGovernment strategies and legislation regarding issues of identification and authentication. ${ }^{22}$ The private company Nets/DanID A/S is responsible for issuing OCES certificates.

\section{Estonia}

Estonia is considered to be one of the most developed countries in the field of eGovernment. Therefore, it will be interesting to see how the issue of identification and authentication is regulated for the purpose of providing and using eGovernment services. Another reason for choosing this country was the fact that mobile phone authentication was introduced in Estonia.

\section{1 eGovernment in Estonia}

Many strategic documents have been adopted in Estonia covering various eGovernment areas since 2001. In particular, these strategic documents regulated issues like the information society, information security and cyber security. The last adopted document was the Estonian Information Society Strategy 2014-2020. One of the objectives of this strategy is to modernize eGovernment services and to ensure that citizens have control over the data processed in their use. $^{23}$

The cornerstone of eGovernment in Estonia is the so-called X-Road system, which was introduced in 2001. All public authorities can create their own information systems and databases. Therefore, they need to be linked. X-Road is an interface that provides connectivity between different databases and public administration information systems that are decentralized. In addition, $X$-Road also provides secure access to most national databases, provides the necessary accessibility, integrity, and confidentiality when exchanging electronic documents on the Internet.

eGovernment issues are regulated by various legal acts at present. In connection with identification and authentication, the Identity Documents Act which regulates the issue of an electronic identity card plays an important role. ${ }^{24}$ Another legislation regarding issue in question is the Electronic Identification and Trust

22 The abovementioned legislation was the result of a strategy called the Common Digital Strategy for 2011-2015. The aim of this strategy was to replace paper forms and classical delivery by post in electronic form by 2015 . Another area of the strategy in question was digital welfare. In addition, the strategy was dealing with digital public cooperation. For more information see: THE EUROPEAN COMMISSION. eGovernment in Denmark. Brussels, 2016, p. 16-17.

23 THE EUROPEAN COMMISSION. eGovernment in Estonia. Brussels, 2016, p. 17-22.

24 Identity Documents Act regulates 10 types of documents, including an electronic identity card. [online]. Available at: <https://www.riigiteataja.ee/en/eli/ee/504112013003/consolide/current $>$. 
Services for Electronic Transactions Act which regulates the issue of trust services and trust service providers. ${ }^{25}$

\subsection{Identification and authentication}

Estonia has a rich tradition of identification and authentication for the use of eGovernment services since it has already begun in 1997 to implement the first steps for the development of identity cards with electronic functionality. This process was completed in January 2002 when the first electronic identity cards were issued. Estonia is known for its positive approach to modern ICTs and its introduction into public administration ${ }^{26}$. The result of these tendencies was the introduction of possibility to identify and authenticate to eGovernment services through a mobile phone.

Access points for eGovernment services provided to Estonian citizens and entrepreneurs are available at the eGovernment central portal eesti.ee. ${ }^{27}$ Access to this portal requires identification and authentication through an electronic identity card or its mobile form. Identification and authentication can also be performed through the authentication interface of various banks.

\section{Electronic identity card $^{28}$}

The holder of an electronic identity card can be any citizen of Estonia and a person with a residence permit older than 15 years. This card fulfills the functions of a physical identity document as well as a valid travel document within the EU. In addition, it has several electronic features. ${ }^{29}$ Firstly, it serves to prove the electronic identity in the cyberspace. Secondly, it serves to create a digital signature in the use of eGovernment services as well as the private sector.

The electronic identity card is a polycarbonate card that contains an electronic chip. This chip contains personal information ${ }^{30}$ and two X.509 certificates, in particular:

25 [online]. Available at: <https://www.riigiteataja.ee/en/eli/527102016001/consolide $>$.

26 Among the users of the e-services in Estonia are also so-called „e-residents“, see: KERIKMÄE, Tanel, SÄRAV, Sandra. Legal Impediments in the EU to New Technologies in the Example of E-Residency, Baltic Journal of Law \& Politics, 2016, vol 8, no. 2

27 List of eGovernment services available at: $<$ https://www.eesti.ee/eng/services $>$.

28 More than 1.2 million electronic identity cards are active in Estonia, representing $94 \%$ of the total population (1.3 million) at present. [online]. Available at: $<$ https://e-estonia.com/ component/electronic-id-card/>.

29 In 2005, an electronic identity card was used for the electronic election. While in the first local elections in 2005, only $1.9 \%$ of the eligible voters voted in electronic form, in the European Parliament elections in 2015 elected 30.5\% of eligible voters electronically. [online]. Available at: $<$ https://e-estonia.com/component/i-voting/>.

30 The electronic chip contains all the data (except photo and handwritten signature) that are on the front and back of the electronic identity card. 
a) an authentication certificate for the electronic identification, encryption and electronic signature of e-mails. It contains the holder's name, personal identification code $\mathrm{e}^{31}$ and the unique e-mail address of its holder in the form ID_code@eesti.ee. ${ }^{32}$ This e-mail address is assigned lifetime and serves as a reference delivery address. In addition, it serves also for delivery from public authorities as well as private entities. The email address is listed in the public register. ${ }^{33}$

b) digital signature certificate for digital signature creation. It is a qualified certificate for creating a qualified electronic signature within the meaning of the eIDAS Regulation. This certificate includes the holder's name and personal identification code.

The electronic chip also contains two private keys that are protected by two different PIN codes. The validity of certificates is linked to the validity period of the electronic identity card, which is five years. ${ }^{34}$

In addition to the electronic identity card with PIN codes and valid certificates, a card reader and a device connected to the Internet where the software for the electronic identity card is installed is necessary for the use of eGovernment services. $^{35}$

\section{Mobile ID ${ }^{36}$}

An electronic identity card may also be issued in a mobile form (hereinafter referred to as "Mobile ID"). Mobile ID has begun to be used in 2007 by the EMT mobile operator in cooperation with several banks and the Certification Center (AS Sertifitseerimiskeskus). It is possible to electronically authenticate and create a digital signature based on the certificates associated with the mobile phone SIM card through the Mobile ID. In other words, the SIM card of the mobile phone has become the same identification document as the electronic identity card. Mobile ID is valid for five years. ${ }^{37}$

31 Certificates are linked to different registers via a personal identification code that identifies Estonian citizens and eGovernment users. The personal identification code represents the national identifier.

32 ID_code is a personal identification code.

33 ROSOL, Ivo. Elektronické OP v EU. Poučíme se ze zkušeností zemí, které vydaly a používají eOP? [online]. Available at: <http://2009.smartcardforum.cz/downloads/prezentace/IVO_ ROSOL_ELEKTRONICKE_OP_V_EU.pdf $>$.

34 Section 20 of Identity Document Act.

35 [online]. Available at: $<$ http://www.id.ee/index.php?id=30500>.

36 From available resources in 2013, there are more than 40,000 Mobile ID users in Estonia. See, MURPHY, Alix. Estonia's Mobile-ID: Driving Today's e-Services Economy. GSMA. 2013, p. 4.

37 Pursuant to Section 203 of the Identification Documents Act, Mobile ID also expires if the person does not have a valid contract with a mobile carrier. 
Mobile ID uses public key infrastructure (hereinafter referred to as "PKI") technology that provides the highest level of security for various transactions (including online payments) or data transfer. The use of this electronic identification means has the same legal effects as an electronic identity card. ${ }^{38}$

In the case of Mobile ID, it is necessary to conclude a contract with a mobile operator. At present, three mobile operators (Telia, Elisa, and Tele2) are allowed to offer the Mobile ID. The contract is concluded personally, where the person has to prove his identity by valid electronic identity card and passport. Subsequently, when the mobile operator issues the SIM card ${ }^{39}$ that supports the Mobile ID, the person must activate it through the Police and Border Guard Board website. During this activation, a person is required to have a valid electronic identity card with both PIN codes (for electronic identification and digital signature) and valid certificates ${ }^{40}$ Mobile ID allows citizens to easily use electronic services like tax returns through vehicle registration, purchase train tickets or gas bill payments.

\subsection{Entities responsible for identification and authentication}

The issue of electronic identification and authentication is under the authority of the Ministry of Interior of Estonia. Electronic identity cards are issued by the Police and Border Guard Board. The certificate service provider is the Certification Center (AS Sertifitseerimiskeskus), which is the only certification authority in Estonia. The Certification Center is responsible for PKI, issuing certificates and inserting personal data into an electronic chip. The private company Trüb Baltic $A S$ is responsible for making the electronic identity card and its personalization.

On the basis of the abovementioned, it can be stated that electronic identity management is based on a partnership between the public administration (Police and Border Guard Board) and the private sector (AS Sertifitseerimiskeskus and Trüb Baltic AS).

\section{New Zealand}

New Zealand is a country with a long tradition of providing public services. However, it is questionable how this country has dealt with the introduction of modern ICTs that have significantly changed the character of identification and

38 It is also possible to talk about two certificates in the case of Mobile ID (authentication certificate and digital signature certificate), as in the case of an electronic identity card. The difference is only in the use of an authentication certificate that serves to authenticate and secure e-mail but does not require encryption. For more information, see Terms and Conditions for Use of Certificates of Personal Identification Documents of the Republic of Estonia available at: <https://www.politsei.ee/dotAsset/674066.pdf $>$.

39 There are two PIN codes on the SIM card that support Mobile ID. One for identification and the other for creating a digital signature.

40 Every person can have only one Mobile ID. Some mobile operators also offer Mobile ID activation at their stores. Procedure available at: <https://www.politsei.ee/en/teenused/ isikut-toendavad-dokumendid/mobiil-id/>. 
authentication in other countries. The primary reason for selecting New Zealand was the fact that it is a country outside the European Union. Another reason was the fact that for identification and authentication purposes is used service that is not based on an electronic identity card or its mobile version. ${ }^{41}$

\section{1 eGovernment in New Zealand}

The beginnings of eGovernment in New Zealand could be dated in 2001 when the first eGovernment Strategy was adopted. This document defines primary strategic goals in the field of eGovernment with New Zealand's vision as a world leader in eGovernment. The subject of this document were priorities such as citizens' access to public sector information and services, the possibility of online transactions, communication of citizens with elected representatives, etc. The eGovernment Unit which was set up in 2000 as part of the State Service Commission had the primary responsibility for meeting these goals. The eGovernment Unit was specifically responsible for developing the eGovernment strategy and creating standards and guidelines. ${ }^{42}$

The result of the work of the eGovernment Unit was the implementation of the project called Secure Electronic Environment. The purpose of the project was to create a secure environment for exchanging emails between public sector entities. In addition, the National Information Infrastructure Protection Strategy was also adopted to create a framework for information protection. ${ }^{43}$

The latest strategy document on eGovernment was the government's ICT Strategy $2015 .^{44}$ Digital services are one of the five priorities of the document in question. In this regard, procedures should be rationalized for the provision of

41 New Zealand took 13th place with a score of 76.66 in a survey called 2015 WASEDA - IAC INTERNATIONAL E-GOVERNMENT RANKING SURVEY. This survey is often used in the literature and was created by Waseda University in Tokyo. Singapore ranks first with 93.80 points. Criteria for evaluating eGovernment were for example, digital infrastructure, online services, a national portal, open data or cyber-security. For more details see: OBI, Toshio. 2015 Waseda - IAC international e-government ranking survey. Institute of e-Government, Waseda University, 2015, 35 p.

42 MILLAR, Laurence. Networking government: e-government in New Zealand. In Public Sector Journal, 2004, Vol. 27, No. 4, p. 3. We could include among the most important standards and directives: Government Web Guidelines, eGovernment Interoperability Framework, Best Authentication Solutions Framework, and eGovernment Delivery Architecture.

43 The biggest problem in implementing the above objectives was the fact that many public sector entities had their own websites through which they provided electronic services independently of other public sector entities. The Government Web Standard was adopted in 2007. This standard helped to increase the number of electronic services available through one access point, government portal gow.nz, as well as has gradually eliminated the undesirable state of non-uniform provision of electronic services. See PODDER, Braja. Evaluating Local e-Government in New Zealand: A Socio-Technical Approach. PhD Thesis. Auckland University of Technology, Faculty of Business and Law, 2013, p. 30-31.

44 [online]. Available at: <https://www.ict.govt.nz/strategy-and-action-plan/strategy/>. 
digital services and the provision of digital services within the federation (not separately for each public sector entity). The result of this priority should be integrated digital services in which citizens trust. ${ }^{45}$

The issue of eGovernment is regulated by a number of legal acts. In connection with identification and identification, the most important legal act is the Electronic Identity Verification Act 2012. ${ }^{46}$ The primary purpose of the act in question is to ensure a secure interaction between citizens and public and private sector entities through the legal regulation of identity verification service. The Department of Internal Affairs is responsible for the service in question. The issue of electronic signature is governed by the Electronic Transactions Act 2002. ${ }^{47}$

\subsection{Identification and authentication}

An access point for electronic services provided by the state is the government portal govt.nz, which was established in 2002. Through this portal, citizens have access to information and services provided by the state via the Internet, the telephone and other ICTs.

The identification and authentication of persons using electronic services provided by New Zealand public sector through the Internet is based on a solution resulting from an association between the Department of Internal Affairs and New Zealand Post. This cooperation resulted in the creation of a service called RealMe. ${ }^{48}$ The previously mentioned identity verification service is part of RealMe. In order to understand this electronic identification means, I will focus on the steps the citizen must undertake to use electronic services through RealMe. First of all, a New Zealand citizen must set up a RealMe account. There are two levels of RealMe account. ${ }^{49}$ The first is an unverified RealMe account and the other is a verified RealMe account. The main difference between these levels is that in the case of an unverified RealMe account, a citizen can access only a limited number of electronic services where strong authentication is not required. In the case of verified RealMe account, it can be used in the cyberspace as an identity confirmation and the person can also access electronic services that require strong authentication. ${ }^{50}$

45 ICT Strategy 2015 available at: <https://www.ict.govt.nz/strategy-and-action-plan/strategy/digital-services/>.

46 Available at: <http://legislation.govt.nz/act/public/2012/0123/latest/whole. html\#DLM1777862>.

47 Available at: <http://www.legislation.govt.nz/act/public/2002/0035/latest/DLM154185. html>.

48 The predecessor of RealMe was iGovt, which focused on modernizing public services by providing online and securely through verified sign-up.

49 RealMe account can also be set up by non-New Zealand citizens. These persons must show valid visas or other documents.

50 According to available data 4.06 million logins was made, 456,778 verified RealMe identities was created and 82.9 million online transactions were made. Figures last updated 4 
To create an unverified RealMe account, it is sufficient to enter e-mail address, login name, mobile phone number, password, and three security questions with the answer. The name, surname, and address are not required.

In the case of a verified RealMe account, the person must first sign in and submit a request online at the RealMe website. ${ }^{51}$ Once the application number has been received by e-mail or text message, the person must go to the New Zealand Post with the application number, passport, or citizenship unique identifier, to create a person's photo. This phase is key for creating an electronic identity because employee of post office use this photo (along with other information) to link the real identity of a person with an electronic identity to RealMe. The New Zealand Post sends this photo to Department of Internal Affairs, which checks this photo with other photographic records of that person (e.g. a photograph on a passport). The photo is used to verify the person's identity. In the last step, the person will be informed of the confirmation that the identity has been verified. ${ }^{52}$

In general, we could say that RealMe is an online identity verification service whereby a citizen can use nationally, locally and privately-operated electronic services after entering his username and password. ${ }^{53}$

RealMe is based on a two-factor authentication, which means that when you enter your username and password, a person will receive a unique code to the mobile phone. The person has to manually enter the code into a specific service so that it can be authenticated via RealMe. Two-factor authentication is considered to be a strong authentication mechanism since for the abuse of electronic identity it is not enough to obtain only the persons login name and password, but also the mobile phone or SIM card. The person who created the RealMe account has complete control over the data that is processed during the provision of a specific service.

\subsection{Entities responsible for identification and authentication}

In general, we could say that the identification and authentication of individuals is the responsibility of New Zealand Department of Internal Affairs, which is responsible for the identity verification service that is part of RealMe. The New Zealand Post also plays an important role in the process of creating an electronic identity, which creates a photograph of the person who serves to verify the identity of a particular person. In the context of the creation of standards for authentication, the State Service Commission plays an important role.

June 2018. [online]. Available at: <https://www.realme.govt.nz/about-us/>.

51 In this application, the person fills in the passport, birthdate data, etc.

52 The process how to verify the identity available at: <https://www.realme.govt.nz/termsuse $/>$. In addition to identity verification, the person may also request an address verification.

53 A list of public sector and private sector entities that recognize the RealMe service available at: $<$ https://www.realme.govt.nz/what-it-is/where-to-use-realme/>. 
Table - Identification and authentication in selected states

\begin{tabular}{|c|c|c|c|c|}
\hline State & $\begin{array}{c}\text { Electronic } \\
\text { identification } \\
\text { means (EIM) }\end{array}$ & $\begin{array}{c}\text { Physical } \\
\text { presence } \\
\text { of the EIM } \\
\text { applicant }\end{array}$ & Authentication method & $\begin{array}{c}\text { The pos- } \\
\text { sibility to } \\
\text { create digital } \\
\text { signature }\end{array}$ \\
\hline Slovakia & eID & YES & $\begin{array}{c}\text { Strong authentication token } \\
\text { (certificates in the smart card) } \\
\text { and security personal code }\end{array}$ & YES \\
\hline $\begin{array}{c}\text { Den- } \\
\text { mark }\end{array}$ & NemID & NO & $\begin{array}{c}\text { Two factor authentica- } \\
\text { tion (login password and } \\
\text { one-time password) }\end{array}$ & YES \\
\hline Electronic \\
identity card
\end{tabular}

Source: Own arrangement

\section{Positive aspects of identification and authentication in selected states}

Denmark represents a country that does not have a tradition in physical identity cards and therefore has come to the solution of identification and authentication in the cyberspace by creating a new model. The Danish NemID as an electronic identification means was created on the basis of cooperation between the public sector and the private sector. Through NemID and the NemLog-in authentication platform, citizens can access various electronic services provided by the public sector as well as the private sector. Citizens of Denmark have high trust in the public sector, which is reflected in trust in the electronic identification means. Among the most important benefits of this electronic identification means we consider the possibility of creating a digital signature.

In Estonia, there are several ways to identify and authenticate for the use of electronic services, in particular, an electronic identity card and a Mobile ID. These electronic identification means use PKI, enabling citizens to use electronic services in the public sector as well as the private sector when a high level of trust and security is ensured. An important electronic functionality of these electronic identification means is the creation of a digital signature that has the same legal 
effects as a handwritten signature in the physical world. A digital signature that has found its use not only for signing electronic documents but also for various transactions where the PKI is used is considered to be a significant positive of electronic identification means applied in Estonia.

The model of identification and authentication in New Zealand, represented by RealMe, was created on the basis of a cooperation of two state entities without the participation of the private sector. The greatest benefit of this electronic identification means is the ability of citizens to decide whether to create an unverified account that serves only as access to some electronic services or to create a verified account that could be considered as officially verified electronic identity of the person they can use cyberspace.

\section{Negative aspects of identification and authentication in selected states}

In the case of the Danish NemID, it could be said that the procedure preceding the obtaining of the NemID card with codes can be a dissuasive element for many citizens. Some citizens can be discouraged by the fact that the electronic token to create one-time codes as a replacement for a card with codes needs to be purchased. With regard to the available documents dealing with identification and authentication, we must state that, compared to Estonia and New Zealand, their number was considerably limited.

The Estonian solution for identification and authentication in the form of an electronic identity card and a Mobile ID is about reproach. Despite the fact that Estonian citizens can identify and authenticate for the use of eGovernment services through modern ICTs, it can be said that these electronic identification means often find more frequent use in the private sector. It could be justified by the fact that citizens do not make interactions and transactions with public administrations on a daily basis.

Most negative aspects can be found in the case of RealMe, which is used in New Zealand. On the basis of the number of verified RealMe accounts $(456,778)$, it is clear that this electronic identification means has not yet found a way to New Zealand citizens. Another negative aspect is that RealMe does not support the creation of a digital signature. Furthermore, the process of creation of verified RealMe account when a person has to go to post office to create a photo that serves to verify identity can be considered as a dissuasive effect on many citizens.

\section{Conclusion}

An analysis of electronic identification means in Denmark, Estonia and New Zealand has shown us other ways of identification and authentication than we know in Slovakia. The equivalent of the Slovak electronic identity card is the Estonian electronic identity card. However, unlike our electronic ID card, the Estonian electronic identity card is used in the private sector and for the use of 
electronic services such as the purchase of tickets for public transport. Mobile ID is the best example of the electronic identification means that should be applied in Slovakia. I believe that introduction of mobile phones for the use of eGovernment services as well as the creation of an electronic signature would positively influence the use of eGovernment services.

It is necessary to point out that even the most advanced electronic identification means do not guarantee that citizens will use it as a primary means of accessing eGovernment services. Citizens communicate and perform various public administration transactions only sporadically. It is necessary to ensure that public administration provides a sufficient amount of eGovernment services that can be realistically used. In addition, it is necessary to look for new ways of use for electronic identification means like purchase a ticket for public transport, electronic elections, or sign up for a university student account.

\section{References}

ANDRAŠKO, Jozef. Electronic identification and authentication in the context of electronic public administration services. In CER Comparative European research 2016, Issue 2, London: Sciemcee publishing, 2016, p. 75-78. [online]. Available at: <http://www.cer-sciemcee.com/previous-years $>$.

ANDRAŠKO, Jozef. Theoretical aspects of public administration electronic services. In Bratislava law review, 2017, Vol. 1, Issue 2, p. 119-128.

ANDRAŠKO, Jozef, ŠURKALA, Ján. The concept of local self-government in the Slovak Republic. In Administrative law and process, 2015, Vol. 12, Issue 2, p. 321-332. [online]. Available at: <http://applaw.knu.ua/2015-2.pdf >.

KERIKMÄE, Tanel; HOFFMANN, Thomas; CHOCHIA, Archil. Legal Technology for Law Firms: Determining Roadmaps for Innovation. Croatian International Relations Review, 2018, vol. 24, no. 81, 91-112.

KERIKMÄE, Tanel, SÄRAV, Sandra. Legal Impediments in the EU to New Technologies in the Example of E-Residency, Baltic Journal of Law \& Politics, 2016, vol 8, no. 2.

MESARČÍK, Matúš. Naozaj sa bojím tmy? Zopár úvah o technologickom determinizme v kontexte ochrany osobných údajov. In Acta Facultatis Iuridicae Universitatis Comenianae, 2017. Vol. 36, No. 2, p. 204-217.

MILLAR, Laurence. Networking government: e-government in New Zealand. In Public Sector Journal, 2004, Vol. 27, No. 4, p. 1-10.

MURPHY, Alix. Estonia's Mobile-ID: Driving Today's e-Services Economy. GSMA. 2013, 20 p.

OBI, Toshio. 2015 Waseda - IAC international e-government ranking survey. Institute of e-Government, Waseda University, 2015, 35 p.

PODDER, Braja. Evaluating Local e-Government in New Zealand: A Socio-Technical Approach. PhD Thesis. Auckland University of Technology, Faculty of Business and Law, 2013, 322 p. 
ROSOL, Ivo. Elektronické OP v EU. Poučíme se ze zkušeností zemí, které vydaly a použivají eOP? [online]. Available at: <http://2009.smartcardforum.cz/downloads/prezentace/IVO_ROSOL_ELEKTRONICKE_OP_V_EU.pdf $>$.

Regulation (EU) 2016/679 of the European Parliament and of the Council of 27 April 2016 on the protection of natural persons with regard to the processing of personal data and on the free movement of such data, and repealing Directive 95/46/ EC (General Data Protection Regulation)

Regulation (EU) No 910/2014 of the European Parliament and of the Council of 23 July 2014 on electronic identification and trust services for electronic transactions in the internal market and repealing Directive 1999/93/EC

Act No. 305/2013 Coll. on the Exercise of Public Authorities Competences in Electronic Form and on changes and amendments to certain acts

Act No. 224/2006 Coll. on Identity Cards and Amendment and Supplementation of Certain Act

Decree of the Ministry of the Interior of the Slovak Republic no. 29/2017 Coll. which sets out the details of the alternative authenticator

Identity Documents Act. [online]. Available at: <https://www.riigiteataja.ee/en/eli/ ee/504112013003/consolide/current>

Electronic Identification and Trust Services for Electronic Transactions Act. [online]. Available at: <https://www.riigiteataja.ee/en/eli/527102016001/consolide>

THE EUROPEAN COMMISSION. eGovernment in Estonia. Brussels, 2016, 48 p. THE EUROPEAN COMMISSION. eGovernment in Estonia. Brussels, 2016, 53 p.

$<$ https://joinup.ec.europa.eu/sites/default/files/inline-files/eGovernment_in_Denmark\%20_March_2017_v2_00.pdf>

$<$ https://www.digst.dk/Servicemenu/English/Policy-and-Strategy/Mandatory-digital-self-service>

$<$ https://www.digst.dk/Servicemenu/English/Policy-and-Strategy/Digital-Postfrom-public-authorities $>$

$<$ https://www.nemid.nu/dk-da/om-nemid/historien_om_nemid/oces-standarden/ oces-certifikatpolitikker/OCES_employee_certificates_version_4.pdf>

$<$ https://www.nemid.nu/dk-da/om-nemid/historien_om_nemid/oces-standarden/ oces-certifikatpolitikker/>

$<$ https://e-estonia.com/component/electronic-id-card/>

$<$ https://e-estonia.com/component/i-voting/>

$<$ http://www.id.ee/index.php?id=30500>

$<$ https://www.politsei.ee/dotAsset/674066.pdf>

$<$ https://www.politsei.ee/en/teenused/isikut-toendavad-dokumendid/mobiil-id/>

$<$ https://www.ict.govt.nz/strategy-and-action-plan/strategy/>

$<$ https://www.ict.govt.nz/strategy-and-action-plan/strategy/digital-services/>

$<$ http://legislation.govt.nz/act/public/2012/0123/latest/whole.html\#DLM1777862>

$<$ http://www.legislation.govt.nz/act/public/2002/0035/latest/DLM154185.html>

$<$ https://www.realme.govt.nz/about-us/>

$<$ https://www.realme.govt.nz/terms-use/>

$<$ https://www.realme.govt.nz/what-it-is/where-to-use-realme/ 